\title{
RICARDO AND HABERLER: AN ESSAY ON THE EVOLUTION OF THE ECONOMIC THOUGHT BASED ON THE FOUR MAGIC NUMBERS IN THE INTERNATIONAL TRADE THEORY ${ }^{\circ} \circ$
}

\author{
RICARDO Y HABERLER: UN ENSAYO SOBRE LA EVOLUCIÓN \\ DEL PENSAMIENTO ECONÓMICO DESDE LOS “CUATRO \\ NÚMEROS MÁGICOS” EN LA TEORÍA DEL COMERCIO \\ INTERNACIONAL
}

Flavia Poinsot*

enviado: 11 febrero 2021 - aceptado: 11 marzo 2021

\begin{abstract}
The Ricardian comparative advantage is one key cornerstone in the international trade theory. There is no shortage of textbooks supposing that Ricardo used solely labour as a factor of production. This approach originates with Haberler in the 1930s, who wrote that Ricardo's theory of comparative advantage is robust, but not the labor-cost doctrine, which, Haberler assumed, Ricardo applied. This paper summarizes why Haberler's perspective emerged, essaying an explanation of his way of interpreting Ricardo. To do this, we considered the new research on Ricardo, whose facets to be known seem to renew over time and never end.

JEL Codes: B31, B53, B25, B12, F10.

Keywords: David Ricardo, Gottfried Haberler, theory of value, theory of comparative advantage, Austrian school of thought, epistemology.

This paper is a summary of "David Ricardo vs. Gottfried Haberler: When an Austrian Mind Matches an English Classic Mind", presented in the AAEP in 2019.

$\because$ Poinsot, F. (2021). Ricardo and Haberler: an essay on the evolution of the economic thought based on the four magic numbers in the international trade theory. Estudios económicos, 38(77), pp. 171-185. DOI: https://doi.org/10.52292/j.estudecon.2021.2657.

* Universidad Nacional del Sur, Argentina. ORCID: https://orcid.org/0000-0003-0010-9965. Correo electrónico: flavia.poinsot@uns.edu.ar
\end{abstract}




\section{Resumen}

La teoría de la ventaja comparativa es una de las piedras angulares de la teoría del comercio internacional. Muchos libros de textos citan la teoría ricardiana haciendo hincapié en que Ricardo se basa en la teoría del valor trabajo. Pero este enfoque se origina con Haberler en los años 1930 para quien la teoría de Ricardo es robusta, pero no la doctrina del valor trabajo en la que, supone Haberler, Ricardo desarrolla su idea principal. Este trabajo resume por qué emerge la visión de Haberler en la historia del pensamiento económico, ensayando una explicación de esta interpretación en Haberler y al considerar las nuevas investigaciones sobre Ricardo, un autor cuyas facetas a conocer parecen renovarse con el tiempo y nunca acabar.

Códigos JEL: B31, B53, B25, B12, F10.

Palabras clave: David Ricardo, Gottfried Haberler, teoría del valor, teoría de la ventaja comparativa, escuela austríaca, epistemología. 


\section{INTRODUCTION}

It was the pen of Gottfried Haberler, "the best horse in the Viennese stables" (Schumpeter, 2000, in Boehm, 2015), that the idea that Ricardo posed his model in terms solely of labor became the usual interpretation of the four magic numbers, which, in chapter seven of Ricardo's book, described the comparative advantage theory. More specifically, in Die Theorie der komparativen Kosten und ihre Auswertung für die Begründung des Freihandels of 1930, i.e., The theory of international trade with its implications to commercial policy (1933).

Interesting enough, knowing that perhaps Torrens was the first in establishing the idea, for Haberler, "the only really systematic theory of international trade we possess is the so-called classical theory" and all its component parts "were worked out by such early writers as Hume, Adam Smith and Ricardo" (Haberler, 1933, 1950, p. 3).

While attempting to demonstrate the falsehood of the idea "that the great profits, which are sometimes made by particular merchants" in the foreign markets, "will elevate the general rate of profits in the country", but instead proving that the rate of profits would diminish, rather than increasing, with the foreign trade, Ricardo put on stage a thought developed in his Essay on the Influence of a Low Price of Corn on the Profits of Stock in 1815, the "eighteenth century rule". This rule is a long tradition that states that "it pays to import commodities from abroad whenever they can be obtained in exchange for exports at a smaller real cost than their production at home would entail" (Viner, 1937, pp. 440, in Maneschi, 2004). However, he advances with the real theory, a few paragraphs of chapter seven, and the monetary aspects, which represents its $85 \%$ (Caffarello, 2016, p. 2).

It is in that $15 \%$, in a few paragraphs of the Principles (1817), that he considered the law of comparative advantage, a thought he developed between March and October of 1816 (Maneschi, 1998, in Ruffin, 2002, p. 743). His "four magic numbers" (Samuelson, 1969, in Maneschi, 2004) describe the exchange between the wine of Portugal and the cloth of England (Ricardo, 1817, p. 89). Taking this "celebrated example" (Haberler, 1933, 1950, pp. 128), where Portugal has a comparative advantage over England in wine than in cloth and "England has an absolute disadvantage in cloth, but at the same time she has a comparative advantage in cloth" (p. 128), Haberler pointed out that this scaffolding of the international trade is more consistent than the Smithsonian one, since the Scottish writer assumed that labor is completely mobile between the different branches of the industry in the country, yet "it cannot move from one industry to another if the two industries 
are in different countries". Thus, for Smith the distribution of labor between the countries "happens to be the same as that which would come about under complete mobility", and the international trade takes place "only if each of the two countries can produce one commodity at an absolutely lower production cost ${ }^{1}$ than the other country" (Haberler, 1933, 1950, p. 127). By contrast, Ricardo "starts from another state of affairs, apparently less favorable to Free Trade, which he considers typical", assuming that one of the two countries can produce "both goods with a smaller expenditure of labor (cost) than the other country" (Haberler, 1933, 1950, p. 128).

Then, "in order to discuss the international division of labor", Haberler took the Ricardian ideas, leaving the labor-cost theory in order to construct the "solid" theory of international trade. To do that, the Austrian writer stressed that labor neither is the unique factor nor is it homogeneous and many means of production are specific. Moreover, "there are many different qualities of labor and... other factors of production besides labor are available", such as land, natural resources, and capital, where he included buildings, plant, and equipment. All of them are of different qualities, and, consequently, this makes impossible to "measure all in terms of any one common unit of quantity... they cannot all be resolved into simple unskilled labor" (Haberler, 1933, 1950, p. 175). In a further step, he introduced the Doctrine of Cost Differences, being the theory of comparative costs a special case of it.

We noted that, from the beginning, Haberler did not question that the laborcost theory is the unique theory Ricardo had in mind, but is the problem behind the brilliant idea of the comparative advantage. For example, we may read that the classical doctrine "simplifies reality too much to be adequate". Its assumptions "are never true and some are not always true" (Haberler, 1933, 1950, p. 126). In other words, its suppositions are not correct because its simplicity denies the reality. Moreover, Haberler had in mind a set of assumptions that brings reality into the model, but is "inconsistent with the Labor Theory of Value", which must be discarded (Haberler, 1933,1950, p. 132). In the first place, he introduced money in the analysis, enlarged the model with more than two goods and more than two countries, and considered transport costs and increasing and decreasing costs. In the second place, once the assumptions changed, the next step in his theoretical framework was to apply the general equilibrium theory. That is, "the modern doctrine of economic equilibrium, associated with Menger, Böhm-Bawerk, Wicsteed, Marshall, Walras, Pareto, Schumpeter, Knight" (Haberler, 1933, 1950, p. 175), because the classical theory "is exhibited as a special case of the more general theory" (Haberler, 1933, 1950, p. 3, 123).

1 Italics in the original 
Therefore, we have a few questions about Ricardo's outlook about the laborcost theory and Haberler's interpretation of Ricardo.

\section{THE THEORY OF COMPARATIVE ADVANTAGE: NEW EVIDENCE AND THE EVER-LASTING DILEMMA FOR RICARDO OF THE THEORY OF VALUE}

A correct understanding of what Ricardo did not say implies to analyze, in light of new evidence, the $15 \%$ of chapter seven, having in mind that the "celebrated example" by which Ricardo explained the comparative advantage theory is embodied in few hazy paragraphs, as for example, "The same rule which regulates the relative value of commodities in one country does not regulate the relative value of the commodities between two or more countries". Hence, "the quantity of wine which she [Portugal] shall give in exchange for the cloth of England, is not determined by the respective quantities of labour devoted to the production of each" (Ricardo, 1817, pp. 89-90).

Faccarello (2016) pointed out that Ricardo assigned this to the immobility of capital and labor between countries. Thus, "England would give the produce of the labor of 100 men, for the produce of the labor of 80", but "such an exchange could not take place between the individuals of the same country" (p. 91). Faccarello (2016) then established that "it seems that Ricardo's statement has been accepted as obvious" (p. 12) and "switched to his alternative theory of natural prices". Hence, "when reading Ricardo's development... we must always remember the presence of two theories of natural prices-even if Ricardo thought that" the labor-cost theory "was a good approximation" of the theory of natural prices (pp. 12-13).

Furthermore, there are new investigations that can help us understand what Ricardo said in this respect in his "magic four numbers". The traditional interpretation states that these are the amounts of labor needed to produce one unit of each commodity in each country, that is, labor input-output coefficients. Ruffin (2002), instead, offered a new interpretation that stresses that these numbers are the quantities of labor needed to produce the amounts of wine and cloth actually traded by England and Portugal. As Ruffin pointed out, "this is implied by Ricardo's usage of the terms 'the cloth' and 'the wine' in the second paragraph quoted above, which refer to the amounts traded that were mentioned in the first paragraph" (pp. 741742). Ricardo's proof is "simple, elegant and sublime" (p. 742) and, "with the new interpretation of the four numbers, we see that Ricardo's method is much more direct" (Maneschi, 2002, p. 436). Furthermore, this reinterpretation "has cast a new 
light on it, and at the same time rescued Ricardo from the charge of inconsistency or carelessness. In fact, it shows to great advantage the revolutionary character of Ricardo's contribution" (Maneschi, 2004, p. 435).

Our analysis would be incomplete if we do not recall that the theory of value was a problem that arose with Smith (1776), specifically when he considered the labor-cost and the labor-command theories in Book I. Smith argued that the value of a commodity depends on the quantity of labor embodied in it, but, and here is the problem, at the same time, the value also depends on the labor the commodity commands (see Book I, chap. V and VI).

In a letter written to Trower in July 1821, Ricardo says, "I confess I do not rightly understand what meaning you attach to the words 'exchangeable value', when you say the labour which a commodity can command is what actually constitutes its exchangeable value" (Works, 2004, IX, p. 2). We can observe that Trower used the same words of Smith in the first chapters of the Wealth of Nations (1776). Trower was talking about the labor-command doctrine. However, when the production involves capital and land, as a society develops, a contradiction arises between the labor-cost and the labor-command values. This problem was not perceived at all by Smith, but was understood by Ricardo, "who struggled in some of the most difficult and obscure pages of all economic literature to make the contradiction evident" (Douglas, in Spiegel, 1952, p. 124), the first section of the first chapter of the Principles of Political Economy (1817).

However, as the sections go on, and so his reasoning, Ricardo abandoned his attempts to "rehabilitate" the labor-cost doctrine and, in the fourth and fifth sections, he pointed out a difficulty. But "in order to simplify the problem, for the rest of his discussion, he chose to disregard these troubling factors and to make the heroic assumption that all commodities were produced with capitals of equal duration and with equal rapidity of turnover" (Douglas, in Spiegel, 1954, pp. 125-126).

From here on, in the economic thought, mainly two paths open. On the one hand, the socialist outlook, considering that Ricardo developed the labor-cost theory being the capital embodied labor; and the Cambridge outlook, taking in account that both Smith (1776) and Ricardo discarded the labor-cost theory by replacing it with a total-money costs theory of prices, i.e., the prices of commodities would result from the payments to labor, capital, and land (Taylor, 1960, p. 162). Hence, Ricardo's first chapter is originally associated with a controversy as to the extent to which the price of labor affords good standard for measuring the general purchasing power of money. In this connection, its interest is mainly historical "and 
there is an illuminating article on it by Professor Hollander in the Quarterly Journal of Economics, 1904" (Marshall, in Spiegel, 1954, p. 183).

It should be noted that the classical authors sometimes had vague concepts and confusing ideas, and Ricardo was not the exception. What is more, his abstract way of thinking and his deductive method alongside with his ambiguities and obscurities complicate the understanding of his theories. Certainly, this is the case of the international trade theory and, no doubt, of his treatment of the theory of value. As Marshall pointed out in his essay on Ricardo's Theory of Value, "when his words are ambiguous, we must give them the interpretation which other passages in his writings indicate that he would have wished us to give them". In this way, "if we do this with the desire to ascertain what he really meant, his doctrines, though very far from complete, are free from many of the errors that are commonly attributed to them". As to the theory of value, Marshall added, "to understand him rightly, we must interpret him generously, more generously than he himself interpreted Adam Smith" (Marshall, in Spiegel, 1954, p. 174).

A deeper reading of the works of Ricardo can help us understand his ambiguities in the theory of value, which bothered Ricardo since this became a recurrent theme in his correspondence until the last week of his life. As his correspondence shows, Ricardo changed his ideas over time on the value theory. We can establish that he adopted the labor-cost theory in 1816, as new investigations call attention to. Ruffin (2002) stated that Malthus, by April 1816, answered a letter to Ricardo, "in which he said, 'On the subject of determining all prices by labor... I think you must have swerved a little from the right course." Ruffin pointed to, "Clearly, during Malthus's visit, Ricardo must have informed him of his newly adopted labor theory" (p. 736).

In a letter to Malthus, Ricardo affirmed that, "M. Say has not a correct notion of what is meant by value when he contends that a commodity is valuable in proportion to its utility" (Marshall, in Spiegel, 1952, p. 180). This is a point to have in mind as opposed also to the Austrian outlook, because the price for Ricardo is a function solely of "the competition of the sellers". The demand has no role "because the supply would be regulated by cost of production..." (Marshall, in Spiegel, 1952, pp. 180181). Furthermore, Ricardo wrote, "it is supply which regulates value, and supply is itself controlled by comparative cost of production. Cost of production, in money, means the value of labor as well as profits" (Marshall, 1952, p. 181).

In 1819, in another letter to Say, Ricardo wrote that his idea that labor regulates the value of commodities, "is an opinion that I do everything I can to destroy; but I say that is the relative amount of labor necessary for the production of the 
goods that regulates their relative value" (Works, 1964, letter 352, p. 103). In a letter to McCulloch, he stressed that if he were to write the chapter on value again, he "should acknowledge that the relative value of commodities was regulated by two causes instead of by one". These two causes are the labor and the capital, or, in his own words "the relative quantity of labor necessary to produce the commodities in question, and by the rate of profit for the time that the capital remained dormant, and until the commodities were brought to market" (Works, 1964, p. 131).

In the last weeks of his life, in 1823, Ricardo published a draft that appeared within the Mill-Ricardo's paper first published in 1951. Here he wrote that the measure of a value of a commodity is different from that of Malthus, which only considers the labor factor, "It is not, as the measure of Mr. Malthus, one of the extremes, it is not a commodity produced only by labor". Neither is it a commodity whose value is generated only by utilities, instead its value is between that extreme, that is, labor and capital, because this commodity is "more in accordance with the circumstances in which the majority of commodities are produced" (Works, 2004, p. 282).

The theory of international trade is also subject to the ambiguity of the vocabulary and the confusing ideas and sentences Ricardo employed. As in the theory of value, Ricardo purposely omitted many things necessary for the logical completeness of his argument, but which Ricardo and the authors by this time would regard as obvious. We may recall that Marshall stated that the underlying cause was Ricardo, who was induced with difficulty to publish it, in writing, if he had any readers in view at all, they were chiefly those statesmen and businessmen with whom he associated. Moreover, in a letter to Malthus, about his Principles, Ricardo said that he was but "a poor master of language". Marshall himself pointed out the fact that Ricardo's exposition was as confusing as his thought was profound; and that he used words in artificial senses, which he did not explain, and to which he did not adhere; and he changed from one hypothesis to another without giving notice (Marshall, in Spiegel, 1954, p. 174).

Finally, and in the other extreme, further new investigations stress that Ricardo did not write these passages. Instead, James Mill inserted them or, directly, that Ricardo took them from Robert Torrens. The idea is back in the fact that there are only a few paragraphs in the chapter which "seems to play little or no role in the rest of the book... thus neglecting $85 \%$ of the chapter and, unfortunately, the monetary aspects of the question" (Caffarello, 2016, p. 2).

But, what about Haberler and his interpretation of Ricardo's labor theory? Obviously, Haberler went on the same line that the socialists' outlook, something 
ironic, since Böhm-Bawerk's History and Critique of Theories of Interest, where there is "a detailed and consistently deprecatory criticism" of Rodbertus and Marx, laid the foundation for the critique of Marxism in the Austrian school tradition (Böhm-Bawerk, 1884, 1890, pp. 328-392, in Schulak \& Unterköfler, 2011, p. 34). Moreover, this school has its origins in Carl Menger (1840-1921), who accomplished a radical break not only with the German Historicism, but also with the classical economists.

\section{HABERLER'S INTERPRETATION OF THE RICARDIAN OUTLOOK}

Like Ricardo, the methodology of Haberler opposes the German economists and is closer to the English ones. Therefore, in the international trade, Haberler remarked, "it is not, for example, Germany and England, but individuals or firms located in Germany and England, who carry on trade with one another". But, "the mere fact that a political boundary is involved and that the persons in question are nationals of different countries and, perhaps, speak different languages, is economically irrelevant", a subject that distinguishes him from the classics, since they "believed nevertheless that there was a fundamental difference between home trade and foreign trade" (Haberler, 1933, 1950, pp. 3-4). "For a Frenchman or for a German, trade between France and Germany is foreign trade, whether capital and labour are mobile between the two countries or not". The attitude of the government towards their own country and the rest of the world determines "the comparative homogeneity of the economic system... and its comparative isolation from other countries". Hence, "it is, at any rate, ambiguous to speak, as some German writers have done, of the "unity of the national economy" (Haberler, 1933, 1950, p. 7).

However, Haberler stated that Ricardo's theory "starts from the fact that in international trade, as in all other economic activity, it is the individual economic subject who buys and sells, pays and is paid, grants and receives loans". Thus, from Haberler's Austrian perspective, the problem with the theory of foreign trade of Ricardo is Ricardo's theory of value, which, for Haberler, is the labor-cost one. We can find the origin of this thought in Menger's consideration of the "objective theory of labor cost and value" of the English economists, precisely the point of departure of the break with the English classic school.

For Menger, Smith (1776), and Ricardo (1817), in line with Quesnay (1846), Turgot, and Le Trosne, thinking that "le commerce n'estqu'un échange de valeur pour valeur égale" (p. 305) makes the mistake of regarding the quantities of goods in an exchange while not taking into account the utility. Hence, the English economists 
elaborate the idea that the expenditure of human labor determines the cost. For his thesis, Menger broached the works of Theodor Bernhardi (1849), Roesler (1869), and Komorzynki (1869), who "presented a penetrating criticism of English price theories" (Menger, 1871, 2007, pp. 305-306). Therefore, the theory of production costs as determinants of prices is "among the most egregious of the fundamental errors that have had the most far-reaching consequences" in the economy. Then, "equally untenable is the opinion that the determining factor in the value of goods is the quantity of labor or other means of production that are necessary for their reproduction ${ }^{2}$ ".

This explains the phrase of Haberler, "it is common knowledge that the classical economists used the Labor (Cost) Theory of Value. This theory asserts that goods are exchanged against one another according to the relative amount of labor embodied in them" (p. 126), in another passage, he indicated, "the Theory of Comparative Costs... developed out of the classical Labor Theory of Value" (p. 122).

For the Austrian school, "labor services are only one of the factors of the production process, however, and are not economic goods in any higher degree than the other factors of production including the services of land and capital". Land and capital, as labor, have value, "both to individuals and to society", the "capitalists and landowners do not, therefore, live on what they take away from laborers, but upon the services of their land and capital" (Menger, 1871, 2007, p. 168).

We may also consider the fact that, for Haberler, the classical theorists used the labor-cost theory in order to present the foreign trade theory in such a way that it could serve in their battle against the Mercantilists, so popular by the time. As he pointed to, "the classical theorists were indeed concerned mainly with the bearing of their analysis upon questions of trade policy". Then, "they used" the theory of foreign trade "as a weapon to attack Protection, and this even influenced the form in which they presented it". At this point, he recalled the work of Viner, The Doctrine of Comparative Costs (1932), where this author "even believes that their choice of analytical tools, namely of "real cost" theories, was dictated by their politicoeconomic aim". Then, he stressed, "this theory developed out of the classical Labor Theory of value" (Haberler, 1933, 1950, pp. 121-122).

Many other ideas Haberler displayed in his work help us understand his position about the labor-cost theory. One of the key subjects he related to that theory is the mobility of factors. Haberler stated that, although many of these authors have

2 Italics in the original 
in mind particular movements of labor and capital, as Smith, J. S. Mill, Cairnes, or Taussig, "it can, perhaps, be maintained that... they paid too little attention to the significance of these phenomena" (p. 4). In addition, the classical theory assumes that labor is completely mobile between the different branches of the industry in the country, yet "it cannot move from one industry to another if the two industries are in different countries" (p. 127). This assumption, in Haberler's opinion, is "accepted quite naively by the classical school as the criterion of the international trade" (p. 4).

What we should note is that, for Haberler, this implies the danger of underestimating the theory of comparative advantage or, worse, to reject it. He, apparently, had this idea in mind because he remarked that "somebody or other is always trying to show that the Law of Comparative Cost is valid only under the simple assumptions upon which it was originally formulated" (p. 131). Even more, he added that this theory, while being generally accepted in England and America in the 1930s, had not sympathetic reception in Germany and France, "owing to its close association with the Labor Theory of value, but most Italian economists accept it" (pp. 122-123). Then, his argument is that the problem is not the theory, but the labor-cost theory and the assumptions related to this doctrine. The theory is robust, or in his words, "this in no way robs that theory of its scientific character", and he tried to demonstrate the robustness of Ricardo's theory.

Then, if we try to answer why he considered that Ricardo developed the theory in terms of the labor-cost doctrine, we should say that because he is Austrian! For an Austrian, the classic English-speaking economists work with the objective theory of value. However, we can ask ourselves why Haberler did not try to understand Ricardo's theory in terms of the Cambridge line. It follows from his arguments that he assumed that the classical assumptions are only consistent with the labor-cost theory. However, let us say that Ricardo considered either the labor-cost theory or the theory of natural price to be irrelevant, since for the Austrians the right theory is on a demand side. No price is determined by the supply side. Whether it is the theory of production costs or the labor-cost theory, both are "among the most egregious of the fundamental errors that have had the most farreaching consequences" in the economic theory (Menger, op. cit.); to adopt them may represent an unforgivable sin!

Why can we assert this? Because the cuore of the Austrians is the economically acting individual, and the value has its origins in his appreciation of the goods, as they satisfy his needs. Jaffé (1976) described Menger's individual as one of perpetual needs and a delusional conceit, who is susceptible to errors and persistently worried about the future. The causality, then, goes from the individual to the production pro- 
cess, and so does the value process. When Menger used the term "economizing", he referred to the terms "wirtschaftender Mensch", "wirtschaftendes Individuum", and "wirtschaftende Person". As the translator pointed out, "the adjective "wirtschaftend" does not refer to the properties or motives of individuals, but to the activity in which they are engaged. More specifically, it does not refer to "the profit motive" or to "the pursuit of self-interest”, but to the act of economizing” (Menger, 1871, 2007, p. 48).

For this reason, unlike Jevons and Walras, in the foreword of the Principles, Peter Klein indicated Menger "favored an approach that was deductive, teleological, and, in a primary sense, humanistic ${ }^{3} .$. He was primarily interested in explaining the real world actions of real people". Then, "trade is thus the result of people's deliberate attempts to improve their well-being, not an innate 'propensity to truck, barter, and exchange', as suggested by Adam Smith" (p. 7). Furthermore, the tendency of the classical economists to tackle the economy from the supply side leads them "to group factors of production into broad categories -land, labor, and capital- leaving them unable to explain the prices of discrete, heterogeneous units of these factors". In this sense, Menger "realized that the actual prices paid for goods and services reflect not some objective, 'intrinsic' characteristics, but rather the uses to which discrete units of goods and services can be put, as perceived, subjectively, by individual buyers and sellers" (p. 8).

Then, once Haberler stripped the theory of comparative advantage of that "fundamental error", changing the protective belt in a Lakatosian way, he constructed the "solid" theory. In doing this, Haberler, as Böhm-Bawerk many years before, demonstrated a pragmatic-eclectic attitude since he did not reject the equilibrium theory, when many Austrians did, and mixed the reality features with a tendency to create highly abstract aggregates, something unlike other key works of the Austrians. Perhaps, Ricardo would not accept what Haberler had to say about the labor-cost theory in the comparative advantage theory. Nevertheless, as Haberler could understand the essence of Ricardo, no doubt, Ricardo would have understood the essence of Haberler, if Ricardo were alive, because both were two brilliant minds.

\section{SOME CONCLUDING REMARKS}

It is common knowledge that, from Haberler's works in the 1930s, the comparative advantage theory of Ricardo is mainly associated with the labor-cost

3 Italics in the original. 
theory. In nearly all textbooks of international trade, the traditional interpretation of the theory is that the quantities of commodities represent the amounts of labor needed to produce one unit of them in each country, that is, that they are labor input-output coefficients (Maneschi, 2004).

Haberler understood the essential idea of Ricardo, each country will produce those goods based on its natural resources, its labor, and capital factors, manufacturing more than it requires and exchanging the surplus with other countries against goods which it is less capable of producing or which it cannot produce at all. The problem, in his outlook, is not the idea, but the assumptions that Ricardo used to demonstrate the theory, i.e., the labor-cost theory.

In a way that resembles a Lakatosian "research program", Haberler changed the assumptions and the labor-cost theory, the protective belt, but maintained the hard core, the essential idea of Ricardo. This way is an Austrian one. Evidently, some considerations about the problem that generates the labor-cost theory in the rejection of Ricardo's theory may have urged him to do this. Nevertheless, as we developed in the last section, it is his Austrian outlook what prompted him to reconsider the theory. With this Haberler catapults the labor-theory in Ricardo.

Without a doubt, Ricardo and Haberler were two brilliant minds separated in time and space. For example, De Pablo (2017) considered that.

As a 'seller' of his ideas, he [Ricardo] seems unbeatable. Ricardo sought to convince his countrymen that foreign trade suited them and, for this, he built a numerical example where in England, in both goods, labor productivity is lower, in absolute terms!, than that which exists in Portugal. How is it that the English should trade with another country, where labor is more productive than in its own country? Because the difference in productivity between the two countries is not the same in both products, it is convenient for each of them to allocate their productive resources based on the principle of comparative advantage.

For McCulloch, Ricardo was a man trained in habits of profound thinking, inflexible in his principles, and he never made a speech or gave a vote if he was not well convinced that it was founded on just principles (see McCulloch, in Spiegel, 1954, pp. 168-69). In England, many theories of Ricardo became laws, his opinion was valuable, and he acquired influence and consideration. Marshall admired Ricardo. Ruffin (2002) made this point also, when he cited "the genius which enabled Ricardo... to tread his way safely through the most slippery paths of mathematical reasoning, though he had no aid from mathematical training, had 
made him one of my heroes" (quoted in Keynes 1924b). John Maynard Keynes expressed that "Ricardo was the greatest [most distinguished] mind that found economics worthy of its powers" (Harrod 1951, 467; see also 328; 1946, 182; and Samuelson 1962; in Ruffin, p. 745).

Haberler taught seven generations of Harvard students. Samuelson, who participated in Haberler's first international trade seminar in 1936, reminded us his receptiveness, despite his "stubborn consistency", to new methods and ideas in the light of new evidence (Samuelson 1990, in Boehm, 2015, p. 114). Schumpeter (1954) underlined the ability of Haberler in an occasion of writing about the German economists, who, in his opinion, had problems with the "existing scientific apparatus"; he quotes, among other authors, professor Gottl-Ottlilienfeld, who held a prominent position and had many supporters. Then, Schumpeter added that, "to judge him... we must read his work. The psychic cost of this reading can be significantly reduced, however, by reading instead the review by Professor Haberler of Gottl's methodological writings, reissued in 1925" (1954, p. 934).

Probably, Ricardo would not agree with Haberler on the idea that foreign trade is only based on the labor-cost theory. The theory of value bothered Ricardo throughout all his academic life. And, certainly, we can affirm that Haberler thought that Ricardo did work with the labor-cost theory, because he was an Austrian. Nevertheless, as Haberler captured the essence of Ricardo, Ricardo would undoubtedly have captured the essence of Haberler if they had been able to discuss their ideas among themselves. Why we can be sure of this? Because both were two brilliant minds. And a proof of this is that the theory of foreign trade in almost all the textbooks is the theory of Ricardo and Haberler.

\section{REFERENCES}

Boehm, S. (2015). The best horse in the Viennese stables: Gottfried Haberler and Joseph Schumpeter. Journal of Evolutionary Economics 25(1), 107-115

Caffarello, G. (2016). A calm investigation into Mr Ricardo's principles of international trade. European Journal of the History of Economic Thought 22(5). DOI: 10.1080/09672567.2015.1086011

De Pablo, J. C. (2017). Bicentenario de los principios de David Ricardo. (CEMA, Serie Documentos de Trabajo No. 607). Recuperado de https://ucema.edu. ar/publicaciones/download/documentos/607.pdf 
Jaffé, W. (1976). Menger, Jevons, and Walras De-homogenized. Economic Inquiry 14(4), 511-523. Recuperado de https://doi.org/10.1111/j.1465-7295.1976. tb00439. $\mathrm{x}$

Maneschi, A. (2004). The true meaning of David Ricardo's four magic numbers. Journal of International Economics 62(2), 433-443. Retrieved from https:// doi.org/10.1016/S0022-1996(03)00008-4

Menger, C. (1871, 2007). Principles of economics. Auburn, Alabama: Ludwig von Mises Institute.

Ricardo, D. (1817, 1821, 2001). On the principles of political economy and taxation. Canadá: Batoche Books.

Ricardo, D. (2004). Volume V: Speeches and Evidence. In The works and correspondence of David Ricardo. Edited by Piero Sraffa and M.H. Dobbs. Indianapolis: Liberty Fund.

Ricardo, D. (2004). Volume IX: Letters, July 1821-1823. In The works and correspondence of David Ricardo. Edited by Piero Sraffa and M.H. Dobbs. Indianapolis: Liberty Fund.

Ricardo, D. (2004). Volume X: Biographical Miscellany. In The works and correspondence of David Ricardo. Edited by Piero Sraffa and M.H. Dobbs. Indianapolis: Liberty Fund.

Ruffin, R. J. (2002). David Ricardo's discovery of comparative advantage. History of Political Economy, 34(4), 727-748.

Schulak, E. M., \& Unterkofler, H. (2011). The Austrian School of Economics: A History of its Ideas, Ambassadors \& Institutions. Journal of the History of Economic Thought 34(2). DOI: 10.1017/S1053837212000284

Schumpeter, J. A. (1954, 1971). Historia del análisis económico. España: Ariel.

Spiegel, H. W. (1954). The Development of Economic Thought. Great Economists in Perspective. New York: John Wiley \& Sons.

Taylor, O. H. (1960). A History of Economic Thought: Social Ideals and Economic Theories from Quesnay to Keynes. New York: McGraw-Hill.

Von Haberler, G. $(1933,1950)$. The Theory of International Trade with its Implications to Commercial Policy. London: William Hodge and company, LTD.

(C) 2021 por los autores; licencia no exclusiva otorgada a la revista Estudios económicos. Este artículo es de acceso abierto y distribuido bajo los términos y condiciones de una licencia Atribución-No Comercial 4.0 Internacional (CC BY-NC 4.0) de Creative Commons. Para ver una copia de esta licencia, visite http://creativecommons.org/licenses/by-nc/4.0 
